\title{
Screening Range Grasses for Resistance to Black Grass Bugs Labops hesperius and Irbisia pacifica (Hemiptera: Miridae)
}

\author{
JAMES D. HANSEN, KAY H. ASAY, AND DALE C. NIELSON
}

\begin{abstract}
Resistance to feeding by black grass bugs (Hemiptera: Miridae), Labops hesperius Uhler and Irbisia pacifica (Uhler), was studied in 5 range grasses: 3 crested wheatgrass [Agropyron cristatum (L.) Gaertn., $A$. desertorum (Fisch. ex Link) Schult., and the $A$. cristatum $\times A$. desertorum hybrid], and 2 hybrids between quackgrass [Elytrigia repens (L.) Nevski] and bluebunch wheatgrass [Pseudoroegneria spicata (Pursh) Lövel. The grasses were screened as seedlings in 4 trials with caged insects. Based on the amount of damage, the crested wheatgrass hybrid was the most susceptible and the other hybrids the most resistant. Resistant individuals were also identified within each grass population. No differences were found in feeding preferences of the $\mathbf{2}$ black grass bug species. Clones of crested wheatgrass previously selected as individual seedlings maintained their resistance in subsequent replicated trials.
\end{abstract}

Large areas of the Intermountain West have been seeded with introduced wheatgrasses to increase forage productivity and restore depleted rangelands. When planted as a monoculture, these grasses have been susceptible to infestations of black grass bugs, Labops spp., and Irbisia spp. (Hemiptera: Miridae) (Todd and Kamm 1974, Haws 1978, Ansley and McKell 1982). Haws (1982) has reviewed the economic impacts due to a black grass bug feeding.

Chemical control of insects is often impractical on western rangelands (Campbell et al. 1984). A potentially more effective strategy is to develop plant germplasm that is resistant to insect attack. Hewitt (1980) studied the variation in feeding by Labops hesperius

Authors are research entomologist, research geneticist, and entomologist, USDAARS, Logan, Utah 84322.

The authors extend thanks to B. Austin Haws for identifying black grass bug species, and Jill M. Mangum and Cheryl L. Nowak for their laboratory assistance.

Cooperative investigations of the USDA-ARS and the Utah Agricultural Experiment Station, Logan, Utah 84322. Approved as Journal Paper No. 2829.

Manuscript accepted August 13, 1984.
Uhler on 10 species of wheatgrass and concluded that 4 species showed some tolerance to the feeding. Thus, he proposed that breeding work be initiated to develop resistant lines. Higgins et al. (1977) found differences in susceptibility to $L$. hesperius among Utah range grasses, and this finding also suggested a genetic basis for plant resistance to $L$. hesperius. In contrast, the feeding preferences of Irbisia spp. have been poorly documented.

Painter (1968) recognized the basic mechanisms of resistance as nonpreference, tolerance, and antibiosis, and he stressed how these components frequently interact. Dahms (1972) reviewed the criteria for evaluating plant resistance to insects. Selection for resistance to insect pests has been effective in forage plants, particularly alfalfa (Medicago sativa L.) (Nielson and Lehman 1980).

A simple, rapid method that screens large amounts of plant germplasm for resistance to insect feeding is essential for effective breeding programs. Objectives of this study were to detect differences in feeding damage by black grass bugs among selected grass entries and to develop techniques to routinely screen for resistance.

\section{Materials and Methods}

The grasses tested were 2 commercial cultivars of crested wheatgrass, 'Fairway' [Agropyron cristatum (L.) Gaertn.] and 'Nordan' [A. desertorum (Fisch. ex Link) Schult.]; 1 crested wheatgrass hybrid [A. cristatum $\times A$. desertorum, designated ' $C D$ '; and 2 quackgrass [E. repens (L.) Nevski] $\times$ bluebunch wheatgrass [Pseudoroegneria spicata (Pursh) Löve] hybrids, designated 'RS-1' and 'RS-2'. Grass entries were selected on the basis of similarities in growth rates, leaf structure, and agronomic importance.

Seeds of these grasses were planted in separate rows in $35-X$ $50-\mathrm{cm}$ galvanized trays. Each contained 5 rows and the grass entries were assigned to the rows at random. Trays were arranged on the greenhouse bench as a randomized complete block, with 5 
replications. A control tray was included in each of 4 tests (A, B, C, and D).

The screening study was conducted under greenhouse conditions during the summer of 1982 . A cage with plexiglas sides $(25 X$ $28 \times 47 \mathrm{~cm}$ ) and a fabric screen top was placed on top of each tray. When most seedlings were taller than $40 \mathrm{~mm}$, adult bugs were introduced. Irbisia pacifica (Uhler) from $1 \mathrm{~km}$ east of North Logan, Utah, were used in Test A; Labops hesperius from $11 \mathrm{~km}$ east of Logan, Utah, were used in Tests B and D; and L. hesperius from $27 \mathrm{~km}$ east of Beaver, Utah, were used in Test C. Stocking rate for all tests were 100 bugs per cage except for Test $D$, when only 38 bugs were available per cage.

Because of the narrowness and uniform width of the seedling leaves, linear measurements were used to denote leaf amount. Seedling lengths werc measured before bug introduction and again after very severe feeding damage, or, as in Test $D$, after the bugs had died (less than 2 weeks after introduction). Since bugs feed downward from the tops of seedlings, undamaged portions were easily measured from the base of the plants. Differences between total height and amount undamaged were attributed to bug feeding. Percentage of undamaged portion was also determined for each plant. Amount of plant injury was used as criterion for determining resistance (Dahms 1972).

Plants screened for resistance were selected by allowing the seedlings to recover, choosing the 2 tallest of each entry from each cage, and then growing them in separate containers for about a year. Nielson and Lehman (1980) described similar methods for selecting alfalfa seedlings in screening for resistance to aphids. Control plants were taken at random from each cage and were maintained under the same conditions as the screened plants.

In summer of 1983 , selected plants of each grass entry were tested separately with $I$. pacificia in the greenhouse for resistance to feeding. Screened and control clones were arranged together randomly in $25 \times 28 \times 47 \mathrm{~cm}$ plexiglas cages as was done in previous feeding studies (Hansen et al. 1985). Grasses taller than $10 \mathrm{~mm}$ were used, their canopies were allowed to intertwine, and soil was added to form a level surface. Plants in each case originated from the same screen study (A, B, or C). Stocking rates were 100-200 bugs/cage and 3 replicates were used. Feeding damage per plant was rated visually by 2 observers using a scale of 0 (no damage) to 10 (complete destruction) about a week after bug introduction and the scores combined to make the damage rating value.

\section{Results and Discussion}

Although care was taken to assure uniform rearing treatment, seedling heights differed significantly $(P<0.01)$ among trays and entries of the same test. Variability in growth rates may have been due to differences in greenhouse location and genetic variation among and within entries. Except for the very smallest seedlings (shorter than $10 \mathrm{~cm}$ ), no evidence was found to indicate that host selection by the bugs was a function of leaf size.

Damage variables were measured or calculated for all seedlings (Table 1). Because fewer bugs were in Test $D$, the average amounts of damage for the entries were less than half those in the other tests. The 4 criteria used for measuring feeding damage among the entries were not significantly different. Apparently, caged bug populations must be greater than a particular threshold level before differences in feeding behavior can be discerned.

The RS hybrids had significantly $(P<0.05)$ higher percentages and amounts of undamaged leaves than the other entries (Table 1). Although these hybrids often had the longest leaves, leaf size did not appear to be related to susceptibility to black grass bugs within

Table 1. Summary of damage to five grass species and interspecific hybrids by Irbisia pacifica (Test A) and Labops hesperius (Tests B, C, and D).

\begin{tabular}{|c|c|c|c|c|c|c|}
\hline Test & Entry' & $\begin{array}{c}\text { Number } \\
\text { of } \\
\text { plants }\end{array}$ & $\begin{array}{l}\text { Undamaged } \\
\mathrm{mm} / \frac{\text { seedling }}{x}\end{array}$ & $\mathrm{~mm} / \frac{\text { seedling }}{x}$ & $\frac{\mathrm{mm} / \mathrm{row}}{x}$ & $\begin{array}{l}\% \text { Undamaged/ } \\
\text { seedling } \\
\frac{x}{x}\end{array}$ \\
\hline A & $\begin{array}{l}\text { AGCR } \\
\text { AGDE } \\
\text { CD } \\
\text { RS-1 } \\
\text { RS-2 } \\
\text { LSD }(0.05) \\
\text { CV }(\%)\end{array}$ & $\begin{array}{l}191 \\
172 \\
207 \\
191 \\
193\end{array}$ & $\begin{array}{r}8.7 \\
8.7 \\
14.0 \\
15.7 \\
14.4 \\
3.4 \\
20.6\end{array}$ & $\begin{array}{l}37.8 \\
38.9 \\
54.9 \\
38.4 \\
36.7 \\
12.9 \\
23.3\end{array}$ & $\begin{array}{r}1449.8 \\
1362.6 \\
2294.0 \\
1498.2 \\
1419.4 \\
623.5 \\
29.0\end{array}$ & $\begin{array}{r}22.6 \\
23.7 \\
23.9 \\
32.0 \\
31.3 \\
7.8 \\
21.8\end{array}$ \\
\hline $\mathbf{B}$ & $\begin{array}{l}\text { AGCR } \\
\text { AGDE } \\
\text { CD } \\
\text { RS-1 } \\
\text { RS-2 } \\
\text { LSD }(0.05) \\
\text { CV }(\%)\end{array}$ & $\begin{array}{l}199 \\
204 \\
219 \\
212 \\
194\end{array}$ & $\begin{array}{l}17.6 \\
19.4 \\
18.6 \\
45.4 \\
48.2 \\
10.3 \\
25.7\end{array}$ & $\begin{array}{r}42.1 \\
41.5 \\
58.5 \\
32.5 \\
32.1 \\
5.6 \\
10.1\end{array}$ & $\begin{array}{r}1668.2 \\
1687.8 \\
2552.6 \\
1378.4 \\
1235.2 \\
253.5 \\
11.1\end{array}$ & $\begin{array}{l}27.9 \\
31.0 \\
24.5 \\
56.9 \\
60.0 \\
10.7 \\
19.9\end{array}$ \\
\hline C & $\begin{array}{l}\text { AGCR } \\
\text { AGDE } \\
\text { CD } \\
\text { RS-1 } \\
\text { RS-2 } \\
\text { LSD }(0.05) \\
\text { CV }(\%)\end{array}$ & $\begin{array}{l}186 \\
183 \\
202 \\
200 \\
198\end{array}$ & $\begin{array}{r}7.3 \\
6.7 \\
5.1 \\
16.7 \\
24.1 \\
4.8 \\
30.1\end{array}$ & $\begin{array}{r}41.9 \\
41.3 \\
62.0 \\
43.7 \\
46.6 \\
7.1 \\
11.3\end{array}$ & $\begin{array}{r}1553.8 \\
1515.8 \\
2513.9 \\
1736.2 \\
1845.2 \\
369.4 \\
15.0\end{array}$ & $\begin{array}{r}16.1 \\
14.5 \\
9.8 \\
28.1 \\
34.9 \\
7.3 \\
26.2\end{array}$ \\
\hline$D^{2}$ & $\begin{array}{l}\text { AGCR } \\
\text { AGDE } \\
\text { CD } \\
\text { RS-1 } \\
\text { RS-2 } \\
\text { CV }(\%)\end{array}$ & $\begin{array}{l}205 \\
198 \\
207 \\
200 \\
207\end{array}$ & $\begin{array}{l}47.8 \\
63.9 \\
54.3 \\
55.0 \\
52.1 \\
27.0\end{array}$ & $\begin{array}{l}38.0 \\
29.4 \\
31.5 \\
31.6 \\
27.9 \\
29.4\end{array}$ & $\begin{array}{r}1564.8 \\
1139.4 \\
1307.6 \\
1271.0 \\
1152.2 \\
32.3\end{array}$ & $\begin{array}{l}56.6 \\
65.6 \\
63.1 \\
63.8 \\
65.4 \\
16.3\end{array}$ \\
\hline
\end{tabular}

IAGCR = Agropyron cristatum, Fairway crested wheatgrass.

AGDE = Agropyron desertorum, Nordan crested wheatgrass.

$\mathrm{CD}=A$. cristatum $\times A$. desertorum, crested wheatgrass hybrid

RS-1 = Elytrigia repens $\times$ Pseudoroegneria spicata, quackgrass-bluebunch wheatgrass hybrid 1 .

RS-2 =E. repens $\times E$. spicata, quackgrass-bluebunch wheatgrass hybrid 2 .

2Differences among entries were nonsignificant. 
an entry, except that uninjured leaves grew faster than injured ones.

The rankings of grass entries based on amount of damage were relatively consistent across tests (Table 1 ). The $C D$ hybrid was significantly $(P<0.05)$ damaged the most, whereas the RS hybrids generally showed the least insect damage. Because the value of average damage per seedling probably reflected unequal numbers of germinated seedlings per entry, we also examined the total amount of damage for each entry. This examination confirmed that the CD hybrid was significantly $(P<0.05)$ more susceptible than all other entries.

We can only speculate as to why the CD hybrid tended to be more preferred by the bugs than the 2 parental species. The hybrid was derived from an induced tetraploid of $\boldsymbol{A}$. cristatum. Increased chromosome numbers have been associated with increased cellular levels of soluble constituents, such as sugar, and decreased structural constituents in perennial ryegrass, Lolium perenne L., (Sullivan and Myers 1939, Sullivan 1944). More experimentation is needed to determine the relationship between chemical entities in crested wheatgrass and bug feeding preference. Also, the hybrid grew more actively than $A$. cristatum or $A$. desertorum, and it had more fresh leaf material available at any given time. Assuming that younger more succulent leaves were preferred by the bugs, it would follow that more total leaf area of the CD hybrid would be consumed.

Graphs were made of the frequency distributions of the 5 grasses according to the percentage of undamaged leaves (Fig. 1). The most susceptible entry was identified as the one with the lowest frequency of plants with undamaged leaves. In every test, the crested wheatgrass were more susceptible than the RS hybrids. The small rise of the curves at the maximum value of the $X$ axis represented not only very small plants that were not attacked (escapes), but also resistant individuals. Although resistant plants must be differentiated from escapes, it appears that germplasm to breed resistant lines is available within the populations studied.

In subsequent replicated trials, crested wheatgrass clones previously selected for resistance were generally damaged less than control plants (Table 2). Although some escapes may have been included in the initial screening, resistant plants were identified which can provide germplasm to breed resistant cultivars of crested wheatgrass. The average damage ratings of the selected entries of the RS hybrids were equal or less than those of the controls. Since the RS hybrids were the least susceptible entries in the screened

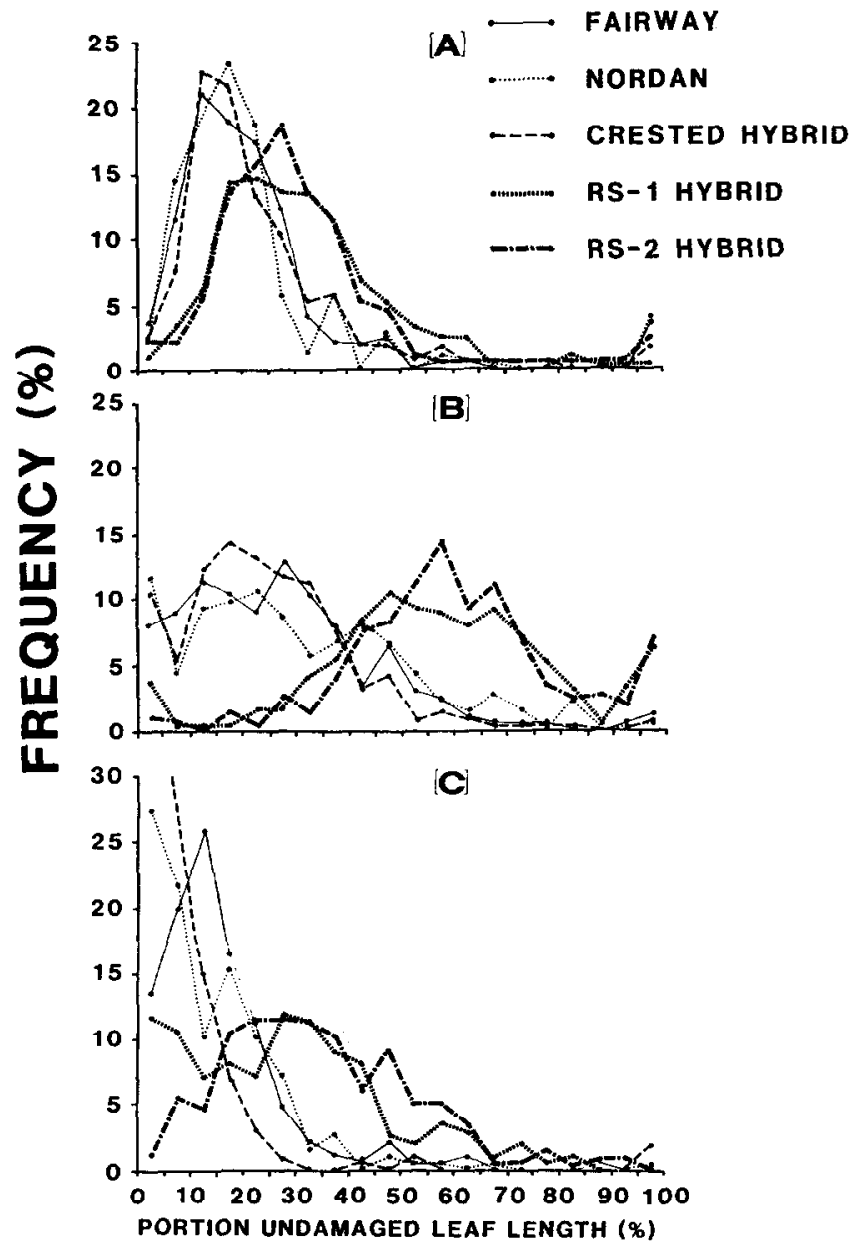

Fig. 1. Frequency distributions (\%) of 5 wheatgrass populations according to the average portions of leaves (seedlings) undamaged (\%) after exposure to Irbisia pacifica (Test A) and Labops hesperius (Tests B and C).

Table 2. Comparison between previously selected and control plants of five grass entries in feeding resistance tests to Irbisia pacifica.

\begin{tabular}{|c|c|c|c|c|c|}
\hline \multirow[b]{2}{*}{ Entry } & \multirow{2}{*}{$\begin{array}{c}\text { Study of } \\
\text { origin of entry }\end{array}$} & \multicolumn{2}{|c|}{ Ratings 1} & \multicolumn{2}{|c|}{ F-test } \\
\hline & & Screened & Control & $\begin{array}{l}\text { Selected vs control } \\
\text { groups }\end{array}$ & $\begin{array}{l}\text { Among genotypes } \\
\text { within groups }\end{array}$ \\
\hline \multirow[t]{4}{*}{ AGCE } & A & 4.8 & 5.5 & 1.76 & $3.04 * *$ \\
\hline & B & 6.1 & 6.1 & 0.0 & $2.70^{* *}$ \\
\hline & $\mathrm{C}$ & 4.7 & 6.5 & $14.82^{* *}$ & 1.77 \\
\hline & $\bar{x}$ & 5.2 & 6.0 & & \\
\hline \multirow[t]{4}{*}{ AGDE } & A & 7.5 & 6.5 & $4.79^{*}$ & $7.77 * *$ \\
\hline & B & 3.6 & 6.2 & $54.95^{* *}$ & $4.18^{* *}$ \\
\hline & C & 4.7 & 6.6 & $24.26^{* *}$ & $5.47^{* *}$ \\
\hline & $\bar{x}$ & 5.3 & 6.4 & & \\
\hline \multirow[t]{4}{*}{$C D$} & A & 4.0 & 4.5 & 2.89 & $4.11^{* *}$ \\
\hline & B & 3.3 & 5.2 & $36.46^{* *}$ & $6.05^{* *}$ \\
\hline & C & 5.0 & 5.5 & 1.92 & $6.03^{* *}$ \\
\hline & $\bar{x}$ & 4.1 & 5.1 & & \\
\hline \multirow[t]{4}{*}{ RS-1 } & $\mathrm{A}$ & 4.1 & 3.4 & $4.91^{*}$ & $2.29^{*}$ \\
\hline & B & 2.6 & 2.9 & 3.02 & $2.62^{* * *}$ \\
\hline & $\mathrm{C}$ & 2.9 & 2.9 & 2.51 & $4.44^{* *}$ \\
\hline & $\bar{x}$ & 3.2 & 3.1 & & \\
\hline \multirow[t]{4}{*}{ RS-2 } & A & 6.1 & 6.1 & 0.00 & $5.19^{* * *}$ \\
\hline & B & 5.3 & 5.7 & 0.69 & $2.71^{* *}$ \\
\hline & $\mathrm{C}$ & 5.3 & 4.0 & $12.83^{* *}$ & $4.19^{* *}$ \\
\hline & $\bar{x}$ & 5.6 & 5.3 & & \\
\hline
\end{tabular}

****Significant at 0.05 and 0.0 ! levels of probability, respectively.

'Mean values of combined scores of two observers for 30 plants. Rating scale: $0=$ no damage, $20=$ highest possible damage. 
tests, the controls randomly taken from those populations should have some resistance. Hence, the difference between selected and control plants should be less than those of the crested wheatgrasses.

The within group variation was significant $(P<0.01)$ in the screened and control groups, which indicated that the plants came from genetically diverse populations (Table 2 ).

\section{Conclusions}

Studies showed that although the CD hybrid was the most susceptible to black grass bugs of the grasses tested, individual resistant plants were identified. Likewise, resistant plants were isolated from Nordan and Fairway, 2 cultivars that seemed to be equally attractive to black grass bugs. The responses of the RS-1 and RS-2 were similar and both were more resistant than the crested wheatgrasses. Perhaps one mechanism of resistance in the RS hybrids was associated with their vigorous biomass production. The fact these hybrids had similar amounts of damage as the other entries yet maintained better growth strongly suggested tolerance as the mechanism of resistance.

No discernible differences were found between the feeding preferences of $I$. pacifica and $L$. hesperius, and this finding strongly indicates that selection for mutual resistance in grasses is practical. If so, $I$. pacifica would be the better test organism for future screening studies because it puts more selection pressure on plant populations over the same period of time and is easier to observe because of its body size. I. pacifica is also more readily available in the field in northern Utah and is easier to maintain in the greenhouse.

\section{Literature Cited}

Ansley, R.M., and C.M. McKell. 1982. Crested wheatgrass vigor as affected by black grass bug and cattle grazing. J. Range Manage. 35:586-590.

\section{POSITION ANNOUNCEMENT}

The Dept. of Animal Sciences and Industry at Kansas State Univeristy is seeking an assistant or Associate Professor in Range Management and Ruminant Nutrition; 40\% Teaching and $60 \%$ Research. Applicant should have a Ph.D. in Ruminant Nutrition and/or Range Management with a strong background in Range Livestock Management and nutrition. An understanding of the economics of grazing livestock is desired. Duties include teaching undergraduate and/or graduate courses in Animal Nutrition and Range Livestock Management, advising undergraduate and graduate students, conducting research programs in Ruminant Nutrition and Range Management and directing the 1156 acre Range Research Center which is within 5 miles of campus. Position is available July 1, 1985. Applications will be accepted until May 15, 1985. Send detailed resume, university transcripts and three letters of recommendation to: Dr. Don L. Good, Head, Animal Sciences and Industry Dept., 138 Call Hall, Kansas State University, Manhattan, KS 66506. Kansas State University is an Equal Opportunity Employer.
Campbell, W.F., B.A. Haws, K.H. Asay, and J.D. Hansen. 1984. A review of black grass bug resistance in forage grasses. J. Range Manage. 37:365369.

Dahms, R.G. 1972. Techniques in the evaluation and development of host-plant resistance. J. Environ. Qual. 1:254-259.

Hansen, J.D., K.H. Asay, and D.C. Nlelson. 1985. Feeding preference of a black grass bug, Labops hesperius (Hemiptera: Miridae), for 16 range grasses. J. Kans. Entomol. Soc. 58: (In press).

Haws, B.A. 1978. Economic impact of Labops hesperius on the production of high quality range grasses. Final Rep. Utah Agr. Exp. Sta. to Four Corners Regional Comm.

Haws, B.A. 1982. An introduction to beneficial and injurious rangeland insects of the western United States. Utah Agr. Exp. Sta. Spec. Rep. 23.

Hewitt, G.B. 1980. Tolerance of ten species of Agropyron to feeding by Labops hesperius. J. Econ. Entomol. 73:779-782.

Higgins, K.M., J.E. Bowns, and B.A. Haws. 1977. The black grass bug (Labops hesperius Uhler): its effect on several native and introduced grasses. J. Range Manage. 30:380-384.

Nielson, M.W., and W.F. Lehman. 1980. Breeding approaches in alfalfa. In: Maxwell, F.G., and P.R. Jennings (ed.). Breeding plants resistance to insects. John Wiley and Sons. New York.

Painter, R.H. 1968. Insect resistance in crop plants. Univ. Press of Kansas, Lawrence.

Sullivan, J.T. 1944. Further comparisons of plants with different chromosome numbers in respect to chemical composition. J. Amer. Soc. Agron. 36:537-543.

Sullivan, J.T., and W.M. Myers. 1939. Chemical composition of diploid and tetraploid Lolium perenne L. J. Amer. Soc. Agron. 31:869-871.

Todd, J.G., and J.A. Kamm. 1974. Biology and impact of a grass bug Labops hesperius Uhler in Oregon rangeland. J. Range Manage. 27:453-458.

\section{POSITION ANNOUNCEMENT}

The Agricultural and Forestry Experiment Station, University of Alaska, is seeking applicants for the position of Research Associate in Animal Science. The position is located in Nome. The individual will conduct reindeer production research, emphasizing herd management, live animal and carcass evaluation, and selection. M.S. in Animal Science or closely related field, practical experience in or thorough knowledge of livestock production and the meat industry, and the ability to camp and work in remote areas of difficult accessability and sometimes foul weather are required. This position provides many research opportunities for an individual possessing initiative, imagination, and desire to work with the fundamental aspects of a primitive but developing livestock industry.

Send resume, transcripts, and three letters of recommendation to: Dr. William B, Collins, Agricultural \& Forestry Experiment Station, 309 O'Neill Bldg., University of Alaska, Fairbanks, Alaska 99701. Tel: 907/474-7293.

UAF is an equal opportunity/affirmative action employer. 